\title{
ANTIBACTERIAL EFFECT OF ORIGANUM VULGARE AND ASSOCIATED HAEMATOLOGICAL AND SERUM BIOCHEMICAL CHANGES IN CHICKENS.
}

\author{
Kawther H. Sabah; ${ }^{1}$ Fatma M. Yousseff ${ }^{1}$ and Ashraf A. Elghoneimy ${ }^{2}$ \\ 1Animal Health Research Institute. \\ 2Department of Pharmacology, Faculty of Veterinary Medicine, \\ Qena, South Valley University.
}

\begin{abstract}
The current study of discovering new antimicrobial compounds in all fields of microbial control has stimulated research regarding the antimicrobial properties of plant compounds. The watery origano extract was investigated for its antimicrobial activity both in vitro and in vivo. The in vitro study was carried out to estimate the antibacterial activity of watery oregano extract against E. coli, Pseudomonas vulgarius, Enterobacter aerogenes, Salmonella species and Staphylococcus aureus isolated from 60 fecal samples of diseased and (liver, intestine, spleen and kidney) of 25 freshly dead broilers collected during an outbreak in small private poultry farm in Ismailia.The obtained results indicated that watery oregano extract was effective against all isolated tested organisms. The in vivo study was established to investigate its efficacy against experimentally induced colibacillosis in broiler chicks. This study was carried on 120 apparently healthy un sexed one day-old broiler (Lohman) chicks. At $15^{\text {th }}$ day, they were randomly allocated into main equal 6 groups (of 20 chicks each). The $1^{\text {st }}$ group was non infected non treated, the $2^{\text {nd }}$ was non infected oregano extract treated, the $3^{\text {rd }}$ was E. coli
\end{abstract}


experimentally infected non treated, the $4^{\text {th }}$ was E. coli experimentally infected and oregano extract treated, the $5^{\text {th }}$ was $E$. coli experimentally infected ciprofloxacin treated and the $6^{\text {th }}$ was E. coli experimentally infected oregano extract and ciprofloxacin treated. All treatments given orally in drinking water, started 48 hour pos infection and continued for 5 consecutive days. At $2^{\text {nd }}, 9^{\text {th }}$, and $16^{\text {th }}$ day post cessation of treatment, 5 birds per group were slaughtered for blood, serum (for some haematological and biochemical studies) and tissue samples (bacteriological reisolation). The obtained findings displayed that, the mortalities were reduced from $25 \%$ in infected non medicated group to $15 \%(G: 4)$ and zero\% in (G:5) and(G:6), respectively. All infected treated groups showed a greater reduction in clinical symptoms and postmortem lesions severity, especially in groups (G:5) and (G:6). The haematological findings revealed an increase in lymphocyte count in $(G: 2),(G: 4)$ and $(G: 6)$. The biochemical study displayed that treatment of infected groups watery oregano extract, ciprofloxacin or both in combination induced an improvement in both liver and kidney functions as compared to infected unmedicated group. In conclusion our results confirm the antimicrobial potential watery oregano extract both in vitro against all isolated tested pathogenic microorganisms in this study and in vivo against experimentally induced colibacillosis in broilers. Additionally, our findings support the use of watery oregano extract in combination with known antibacterial drugs to enhance the immunity and reduce incidence of bacterial resistance. However, further research studies are still needed to verify its antimicrobial effectiveness and to evaluate its protection against pathogens as well as to investigate its mechanism of action. Moreover, the bioassay-guided fractionation procedure to characterize and isolate the antimicrobial constituents is needed. 


\section{INTRODUCTION}

Antimicrobial agents are mostly synthetic chemicals and some agents are limited to use science they cause adverse effects on public health and reluctance by consumers. Therefore, growing attention has been given to natural antimicrobials which are more readily are accepted by consumers (Cown, 1999). Natural plant products have been used since ancient times and their use is increasing nowadays. Plants are used for medical treatment since the prehistoric time (Dragland et al., 2003). A great number of plant species contains various chemical substances exhibiting health benefit properties, anti-oxidative, anti-inflammatory and mainly antimicrobial effects, and their preventive and therapeutic use with animals is increasing. Nowadays, nearly half of the medicines produced in the USA are originated from plants (Cowan, 1999). Besides $40 \%$ of the prescriptions given by the doctors are consists of plant origin medicines in developed countries (Dragland et al., 2003). Oregano (Origanum vulgare L.) is an important Mediterranean herb rich in phenolic compounds with antioxidant and antimicrobial activity (Chun et al., 2005 and Matsuura et al,. 2003). It is a low-growing perennial native to the Mediterranean, Western Asia and North Africa. As a culinary and medicinal herb it was already well known in ancient Greece and Rome. The main component of oregano oil, carvacrol, has strong bacteriostatic and bactericidal properties which predestine oregano for preventive and therapeutically use in animals (Mauch and Bilkei, 2004). As a consequence, plant origin new materials are extensively examined to be used instead of synthetic feed additives (Wang and Bourne, 1998) those were in use since 1950's. 
Oregano has been used for its antibacterial (Ariana et al., 2002; Dursun et al., 2003; Harpaz et al., 2003 and Uslu et al., 2003), antiinflammatory (Youdim and Deans,2000; and Choi et al., 2002), antioxidant (Burt and Reinders, 2003; Botsoglu et al., 2002 and Botsoglu et al., 2003), insecticide (Choi et al., 2002), antispasmodic, expectorant, fungicide (Akgul and Ayar, 1993), antivirutic (Cowan, 1999) properties for centuries. In order to make use of the naturally existing chemicals in the structure of a plant, it is advisable to use such plants in natural forms rather than in processed forms.

The aim of these studies were planned to determine the in vitro antibacterial effects of natural Origanum vulgare $L$ crude extract (watery extract) against bacterial pathogens isolated from diseased and freshly dead chickens during an outbreak in a small poultry farm in Ismailia as well as the in vivo efficacy against induced Escherichia coli infection. Moreover, some haematological and serum biochemical parameters were also investigated.

\section{MATERIAL AND METHODS}

\section{1-First study (In vitro study):}

History and clinical examination: History of diarrhea and depression has been recorded on 250 birds out of 2000 chicks (21 day old) reared in small private poultry farm at Ismailia Governorate. Beside 100 birds were found dead.

\section{Sampling:}

Sixty Fecal samples from diseased birds and specimens (liver, intestine, spleen and kidney) of 25 freshly dead were collected for bacteriological examinations. 


\section{Bacteriological examination:}

Fecal and tissue samples were subjected to bacteriolological examination according to Quinn, et al. (1994) and (2002). Where the colonial morphology, staining and biochemical reactions were done, as well as serodiagnosis for salmonella by using polyvalent $(\mathrm{O})$ antisera Kit (Dade behring Marburg GmbH -USA) D-35001 and for E.coli by using (coli test serum Anti-OK(B) polyvalent 1.

\section{Antibacterial studies:}

Antimicrobial sensitivity test of the isolated bacteria was done on Mueller-Hinton medium (Oxoid) using:

A- Different chemotherapeutic sensitivity discs (Oxoid) namely Cefotaxim (CTX - $30 \mu \mathrm{g}$ ), Ciprofloxacin (Cip-5 $\mu \mathrm{g}$ ), Enrofloxacin

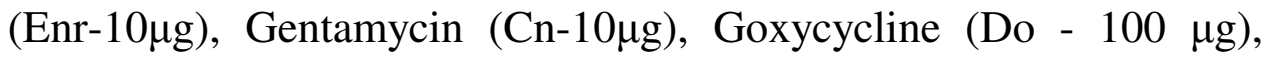
Chloramphenicol (C - $10 \mu \mathrm{g})$, Streptomycin ( $-10 \mu \mathrm{g})$, Erythromycin $(\mathrm{E}-15 \mu \mathrm{g})$, and Trimethoprim/ Sulphamethoxazol (SXT-30 $\mu \mathrm{g})$.

B- Sterile filter paper discs of Origanum vulgare extract: Sterile filter paper discs of $6 \mathrm{~mm}$ were impregnated with $20 \mu \mathrm{l}$ of watery Origanum vulgar extract (oregano tea $1 / 10 \mathrm{v} / \mathrm{v}$ ). The paper discs were allowed to evaporate and after that placed on Mueller-Hinton plates. Then, plates were kept for 2 hour in refrigerator to enable diffusion of the extract into medium.

All plates were incubated over night at $37^{\circ} \mathrm{C}$. The results were interpreted according to NCCLS (2002) standards. 


\section{2- Second study ( In vivo study):}

\section{A- Preparation of watery Origanum vulgare extract (oregano tea 1/10 v/v):}

A 100 grams of crumbled oregano spice (Origanum vulgar L) from a local retailer in Ismailia, Egypt were added to 1 liter of boiled distilled water in a sterile flask. The flask left for 30 minutes at $20^{\circ} \mathrm{C}$ for making oregano tea $1 / 10(\mathrm{w} / \mathrm{v})$. After this time period, the content of the flask was heated $\mathrm{d}$ at $95{ }^{\circ} \mathrm{C}$ for 1 minute, and filtered through sterile cheesecloth to another sterile flask and then, filtered through a filter paper into another sterile flask. The content of the flask was cooled to a room temperature and used in the experiment.

\section{B- Experimental chicks:}

One hundred and twenty apparently healthy unsexed one day-old broiler chicks (Lohman strain) of nearly the same weight were used in this study. Chicks were kept in wire floored battery brooders. They were obtained from Ismailia Miser for Poultry Production Company, Ismailia, Egypt. They were fed non balanced commercial ration free from any medicaments. They are watered adlibitum with a 24 hour light through the experimental period

\section{C- Bacteria:}

The E. coli strain O78:k80 isolated from chickens with coli septicemia during the previous outbreak was used for induction of experimental collibacillosis. The bacteria were grown in a brain heart infusion broth for 24 hours at $37{ }^{\circ} \mathrm{C}$ and on chocolate agar for 24 hours at $37^{\circ} \mathrm{C}$. To prepare the inoculums, the colonies were suspended in $15 \mathrm{ml}$ of sterile saline at $\mathrm{pH}$ 7. The concentration of the suspension was 
determined by McFarland tubes. The number of bacteria per milliliter was determined by plating 10 fold dilutions of suspension on plate count agar. Titers were expressed as colony forming units per milliliter ( $\mathrm{c} \mathrm{f} \mathrm{u}$ $\mathrm{ml}^{-1}$ ) (Fernandez et al., 1998).

\section{D- Experimental design:}

At $2^{\text {nd }}$ week of age, the chicks were randomly allocated in 6 main groups (20 chicks of each). Birds in groups (3, 4, 5 and 6) were experimentally infected by injection of $\left(1.5 \times 10^{8}\right) \mathrm{C} \mathrm{F} \mathrm{U/} \mathrm{ml}$ of $E$. coli (O 78) suspended in saline into the left ventral air sac. The treatment started 48 hour post infection (after appearance of clinical sings) and lasted for 5 successive days. The groups were named as following:

Group (1): The birds of this group were kept without any medications as a control group (G: 1).

Group (2): The chicks of this group were treated with watery Origanum vulgar extract at a dose level of $(50 \mathrm{ml} /$ liter $)$ for 5 successive days (G: 2).

Group (3): The birds of this group were infected with E.coli $\left(1.5 \times 10^{8)}\right.$ and kept with out any treatments (G: 3 ).

Group (4): The chickens of this group were infected with E.coli (1.5 $\mathrm{X} 10^{8}$ ) and treated with watery Origanum vulgar extract a dose level of (50 ml/liter) for 5 successive days (G: 4).

Group (5): The chicks of this group were infected with E.coli $\left(1.5 \times 10^{8}\right)$ and treated with ciprofloxacin ( $1 \mathrm{ml} /$ litre) $(\mathrm{G}: 5)$.

Group (6): The birds of this group were infected with E.coli $\left(1.5 \times 10^{8)}\right.$ and treated with both watery Origanum vulgar extract (50 $\mathrm{ml} / \mathrm{liter}$ ) and ciprofloxacin (1ml/liter) (G: 6). 


\section{E- Clinical examination:}

The birds were examined daily for clinical signs of disease and mortality.

\section{F- Sampling and analysis:}

\section{1- Sampling:}

At $2^{\text {nd }}, 9^{\text {th }}$ and $16^{\text {th }}$ day post cessation of treatment, 5 chickens from each group were slaughtered for sampling and two blood samples from each bird in each group were collected in clean dry centrifuge tubes, one with anticoagulant (EDTA) for haematological study and the other without any anticoagulant (for serum collection) for clinico-biochemical tests. The serum was separated by centrifugation at 3000 r.p.m. for 15 minutes and kept frozen at $-20^{\circ} \mathrm{C}$ until analyzed. Also, tissue samples were obtained for bacteriological reisolation.

\section{2- Analysis:}

\section{a) Hematological analysis:}

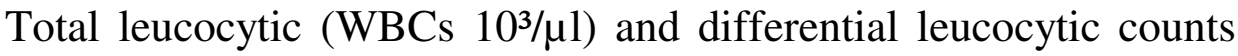
were determined according to routine hematological examination and standard blood smear (Jain, 2000).

b) Serum biochemical analysis: The collected sera were assayed for serum biochemistry. The level of alanine aspartate aminotransferase (AST) and alanine aminotransferase (ALT) according to Reitman and Frankel (1957), creatinine (Young et al.,1975) and uric acid (Caraway, 1963), total serum protein (Henry, 1964), total albumen (Domas, et al., 1975) were determined by using Auto analyzer Hitachi 912. 
C) Statistical analysis: The data were reported as the Mean \pm S.E. Statistical significance was determined using analysis of variance according to (Snedecor and Cochran, 1982). Means were compared by Least Significance Difference (LSD) test at 0.5 significance level (Steal and Torrie (1980).

\section{RESULTS AND DISCUSSION}

Many hundreds of plants worldwide are used in traditional medicine as treatments for bacterial infections (Cooke et al., 2000; Martin and Ernst, 2003; Okoli and Iroegbu, 2004). Scientists from divergent fields are investigating plants a new with an eye their antimicrobial usefulness. A sense of urgency accompanies the search as the pace as species extinction cantinas. Laboratories of the world have found literally thousands of phytochemicals which have inhibitory effect on all types of microorganisms in vitro (Cown, 1999). The current study aimed to investigate the in vitro efficacy of watery Origanum vulgare extract against some prevalent isolates in natural broilers farm outbreak as well as to study its in vivo efficacy against experimentally induced colibacillosis in broilers. The affected chicks showed enteritis, weakness and emaciation due to anorexia (in appetence) and profuse diarrhea. The mortality rate was $1.75 \%$. The most prominent isolates from diseased and freshly dead birds were E. coli (68\%). This result was in consistence with results of Aruji et al., (2004) who reported that, the incidence of E. coli isolated from diseased birds was $21 \%$. Also these findings support the results of Petermanns et al., (1989), Aquirre et al., (1992), Tsubokura et al., (1995) and Middleton and Ambrose (2005) they recorded that E. coli was the commonest bacterium isolated from organs, intestinal tract and cloacae of birds and water fowls. 
The results presented in Table 1 declared that E.coli isolation is followed in prevalence by Pseudomonas aeruginosa (32\%), Proteus vulgaris (29\%), Enterobacter aerogenes (26\%), Salmonella spp. (20\%) and Staphylococcus aureus (14\%) from all samples. These results agree exactly with that reported by Szeness et al., (1979) who isolated Salmonella spp., Staphylococcus aureus and Pseudomonas aeruginosa from intestinal contents and bile of stock ducks. Kirkpatrick and Trexler (1986) who isolated Salmonella from birds in an incidence rate of (1.9\%). Brittigham et al., (1988) who recorded that the prevalence rate of bacterial isolation from coloacal swabs of wild and migrating birds were Pseudomonas spp. (22\%), Salmonella spp. (20\%) and Staphylococcus spp. (15\%). Petermann et al., (1989) who isolated Salmonella from organs (5\%) and intestinal tract $(3 \%)$ of the migrating birds. They added that Salmonella typhimurium was the most frequently isolated Salmonella spp. Also, they isolated Pseudomonas spp. and Staphylococcus spp. Hubalek et al., (1998) who isolated Pseudomonas stutzeri (4.5\%) from fecal samples of migrating birds Pseudomonas spp. was also recovered. Also, these findings agree with Shawkey et al., (2005) who isolated species of the poorly defined genus Pseudomonas from feathers of migrating birds. They are suggesting that birds may have acquired many of these bacteria from the environment. Kobayashi et al., (2007) isolated 19 strain of salmonella typhimurium from 328 cloacal swabs of birds. The serological serotyping of isolated E. coli (Table 2) was found to belonged to O 78 (88.89\%), O1 (22.22\%), O2 (20\%) and O26 (8.89\%). These results were nearly similar to those reported by Fatma Yousseff et al., (2008) who recorded that the serotype O78 was the most common serotype isolated from diseased birds 
followed by $\mathrm{O} 26, \mathrm{O} 1, \mathrm{O} 2, \mathrm{O} 157$ and $\mathrm{O} 111$. The obtained results of antimicrobial sensitivity test revealed that the watery Origanum vulgare extract was found to be effective against all tested isolated microorganisms in this study. Notably, the isolated bacteria were more susceptible to the watery Origanum vulgare extract as compared to the standard antibiotic discs except for ciprofloxacin and enrofloxacin. These findings were supported by Chun et al., (2005) who stated that Origanum vulgare $L$ is an important Mediterranean herb rich in phenolic compounds with antioxidant and antimicrobial activity. Also, these results supported by Dulger (2005) who reported that The Origanum vulgare extracts demonstrated antimicrobial effect against Escherichia coli, Staphylococcus aureus, Klebsiella pneumoniae, Pseudomonas aeruginosa, Proteus vulgaris, Bacillus cereus, Mycobacterium smegmatis, Listeria monocytogenes, Micrococcus luteus, Candida albicans, Rhodotorula rubra and Kluyveromyces fragilis.

Regarding the results of the second part of this study, it was cleared that the experimentally infected non treated birds one day post E. coli (O78 of avian origin) infection showed some clinical symptoms of restlessness, ruffled feathers, loss of appetite, mouth breathing and sneezing. At 48 hour post infection, autopsy of diseased chicks showed several gross pathological lesions such as airsaculitis, severe lung congestion, pericarditis, perihepatitis with kidney and liver congestion as well as general congestion of internal organs indicating septicemia. These results are close to that recorded by Bars and Gross (1997), Mohammad and Foud (2004) in E. coli experimentally infected chickens, 
Hedawy and wassel (2005) and Dalia El-Shazly (2007) in E. coli naturally infected Quails. The E. coli (O78) experimentally infected unmedicated birds showed some mortality $(5 / 20)$ with mortality rate of 25\%. These obtained data are not far from that recorded by Badr (2003) who reported that E. coli (O78) experimentally infected non treated (20 day-old) chicks showed a mortality rate of $40 \%$. Also, these findings are nearly similar to that stated by Dalia El-Shazly (2007) who found that E. coli (O78) experimentally infected un medicated quails elicited some mortalities (13/40) with mortality rate of $32.5 \%$. The birds experimentally infected with E. coli and treated with oregano tea (watery Origanum vulgare extract) displayed slight clinical symptoms with the mortalities being reduced to $(3 / 20)$ with mortality rate of $15 \%$. The postmortem lesions were reduced to greater extent as compared to infected untreated birds. Needless to say, these findings are confirmed by our obtained results regarding in vitro efficacy of watery oregano extract against tested isolated pathogens including E. coli (Table 3), which revealed that watery oregano extract was effective against all tested isolated microorganisms. Oregano (Origanum vulgare) is rich in phenolic compounds and the highest phenolic contents were found in watery extract. Moreover, some phenolic phytochemicals have been shown to have antimicrobial and antifungal activity Chun et al., (2005). Given these notions, one could attribute this antimicrobial activity of watery oregano extract to its higher phenolic phytochemicals. In addition, this might be owing to the immunostimulatory effect of oregano proved by Walter and Bilkei (2004). The birds experimentally infected with E. coli and treated with ciprofloxacin declared complete disappearance of 
clinical symptoms, reduction in lesion scores to greater extent with no mortalities. These results may be attributed to the broad-spectrum activity of the drug against many pathogens. This suggestion confirmed by the findings reported by Sheer (1978) and Bauditz (1990) who found that fluoroquinolones were active against a wide range of Gram-negative, a number of Gram-positive and mycoplasma at low concentrations. These findings are close to those stated by Charleston et al., (1998) who recorded a mortality rate of $6.7 \%$ in E.coli infected chickens treated with enrofloxacin, Abdel-Alim et al., (2000) who reported a mortality rate of zero \% in all E.coli infected and ofloxacin treated chicks, Ibrahim (2005) who recorded a mortality and score lesion of zero \% in all affected organs of E. coli infected and marbofloxacin treated birds and Dalia El-Shazly (2007) who reported a complete disappearance of clinical symptoms with low mortality rate of $15 \%$ and obvious reduction in the lesion score. The concurrent administration of both ciprofloxacin and watery oregano extract to E. coli (O78) infected chickens group divulged a complete disappearance of the clinical symptoms with greater reduction in score lesions with no mortalities. Needless to say, these findings certainly may be aught to the augmented effect of both ciprofloxacin and watery oregano extract.

Regard concerning the haematological findings (Table 4), the infected non treated birds elicited a marked increase in total leucocytic count, heterophile, monocyte and eosinophile at $2^{\text {nd }}$ and $9^{\text {th }}$ day pos cessation of treatment. These results may be attributed to stress condition of infection. This suggestion is confirmed by those found by Fraser et al., (1991) and Jain (1993) who stated that leucocytosis, lymphocytosis 
and monocytosis might be associated with infection. Both infected and non infected birds treated with watery oregano extract showed a significant increase in lymphocytic count at $2^{\text {nd }}$ and $9^{\text {th }}$ day post cessation of treatment. These findings may be aught to the immunostimulant effect of oregano. This suggestion is confirmed by Walter and Bilkei (2004) who mentioned that the oregano has a non-specific immunostimulatory effects on immune cells.

Regarding the results of serum biochemical analysis (Table 5), the obtained findings displayed that, E. coli (O78) infected unmedicated chicks elicited a significant increase in serum AST and ALT levels. Increased serum AST level has been associated with hepatocellular damage in chickens, turkeys and ducks Campbell and Coles (1986). Serum ALT has poor specificity for liver disease and the clinical relevance of an increased ALT values is decreased. For this reason, ALT frequently is omitted from avian clinical chemistry panels Harr (2002). The most common cause of elevated serum AST activity in birds is hepatic disease, while ALT is neither a specific nor a sensitive test for hepatocellular disease in birds and may be useful for the detection of hepatic disease only in carnivorous birds Thrall et al., (2004). The infected birds treated with ciprofloxacin displayed a significant decrease in serum AST and ALT values at $9^{\text {th }}$ and $16^{\text {th }}$ days post cessation of treatment as compared to the infected untreated group. These results are not far from those of Hassan and Gaber (2005) who recorded a significant decrease in serum AST level (one week post ofloxacin treatment and 2 weeks post E. coli infection) in chickens. These findings are also go head in head with the results of Dalia El-Shazly (2007) who showed that marbofloxacin treatment in E. coli infected birds elicited a 
significant decrease in serum AST level at 5 weeks old (2 weeks post marbofloxacin treatment and 3 weeks post infection). The E. coli infected chicks treated with watery oregano extract only or treated with both watery oregano extract and ciprofloxacin denoted a significant decrease in serum AST and ALT values as compared with infected untreated group. Meanwhile, these results are non significant when compared with non infected non treated and non infected oregano treated groups. These findings may be attributed to the antioxidant effect as stated by Zheng and Wang (2000), Pizzale et al., (2002) and Chun et al., (2005) who reported that oregano (Origanum vulgare L) is an important Mediterranean herb rich in phenolic compounds with antimicrobial and antioxidant activity. The antioxidant activity of phenolic compounds in plants is mainly due to their redox properties and chemical structure which can play an important role in neutralizing free radicals, chelating transitional metals and quenching singlet and triplet oxygen by delocalization or decomposing peroxides. The E. coli infected non treated birds displayed a significant increase in serum uric acid and creatinine levels allover the experiment. These findings are close to those of Mellata et al., (2003) who stated that avian pathogenic E. coli belongs to extra intestinal pathogenic group of E. coli, which causes septicemia in poultry. These results are confirmed by Dalia El-Shazly (2007) who recorded a significant increase in creatinine and uric acid levels in E. coli infected non-treated birds along the whole experimental period. The infected chicks treated with ciprofloxacin showed a significant decrease in serum uric acid and creatinine levels at $9^{\text {th }}$ and $16^{\text {th }}$ day post cessation of treatment as compared with infected non medicated group. These results indicating renal tissue improvement and may be owing to the 
therapeutic effect of ciprofloxacin removing the bacteria and minimizing its damaging effect on renal tissues. This suggestion is confirmed by Ibrahim (2005) who reported significant decrease in uric acid level at 4 weeks old (one week post marbofloxacin treatment) in E. coli experimentally infected chickens and Dalia El-Shazly (2007) who recorded a significant decrease in serum uric acid level at 5 and 6 weeks old (2 and 3 weeks post marbofloxacin treatment) as compared with infected non treated group. The E. coli infected birds treated with either watery oregano extract alone or both watery oregano extract and ciprofloxacin in combination induced significant decrease in serum uric acid and creatinine levels at $9^{\text {th }}$ and $16^{\text {th }}$ post cessation of treatment as compared with infected non treated group, meanwhile these changes were non significant as compared with both non infected non treated and non infected watery oregano extract treated groups. These improvements may be aught to both therapeutic effect of both ciprofloxacin as discussed before and the kidney protective effect of watery oregano extract owing to its antioxidant effect of its phenolic compounds content Zheng and Wang (2001), Pizzale et al., (2002) and Chun et al., (2005). The E. coli infected non treated chickens provoked a significant decrease in serum total protein, albumin levels (Table 6), as compared with infected non treated group. These results indicated hepatic damage because liver is responsible for the production of a great proportion of plasma protein Cole (1986). E. coli infected and ciprofloxacin treated birds showed a non significant change in serum total protein, albumin and albumin at $2^{\text {nd }}$ day post treatment as compared with infected non treated group. These findings may be attributed to liver affection, as liver is the source of total proteins Cole (1986). The E. coli infected birds treated with watery 
Antibacterial Effect Of Origanum Vulgare And Associated ...

oregano extract or their combination elicited non-significant changes in total proteins, albumin and globulin at $9^{\text {th }}$ and $16^{\text {th }}$ post treatment as compared with non infected non medicated group; meanwhile these changes are significantly increased when compared with infected non medicated group. These results indicating improvements in hepatic functions because of hepatoprotective effect of watery oregano extract owing to the antioxidant effect of its higher contents of phytophenolic compounds as previously discussed.

Table (1): Incidence of bacteria isolated from diseased and freshly birds.

\begin{tabular}{|c|c|c|c|c|c|c|c|}
\hline \multirow{2}{*}{\multicolumn{2}{|c|}{ Microorganisms }} & \multicolumn{2}{|c|}{$\begin{array}{c}\begin{array}{c}\text { Total } \\
\text { No. of diseased } \\
n=60\end{array} \\
\text { a }\end{array}$} & \multicolumn{2}{|c|}{$\begin{array}{c}\text { Freshly dead } \\
\text { chickens } \\
n=25\end{array}$} & \multicolumn{2}{|c|}{$\begin{array}{c}\text { Total No. of } \\
\text { diseased and } \\
\text { freshly dead } \\
\quad n=85\end{array}$} \\
\hline & & No. & $\%$ & No. & $\%$ & No. & $\%$ \\
\hline E.coli & & 45 & 75 & 23 & 92 & 58 & 68.2 \\
\hline Salmonella spp. & & 10 & 16.67 & 10 & 40 & 20 & 23.5 \\
\hline Ps. aeruginosa & & 20 & 33.33 & 12 & 48 & 32 & 37.6 \\
\hline Proteus vulgarius & & 19 & 31.67 & 10 & 40 & 29 & 34.11 \\
\hline Enterobacter aerogenes & & 12 & 20 & 14 & 56 & 26 & 30.6 \\
\hline Staphylococcus aureus & & -- & -- & 14 & 56 & 14 & 16.47 \\
\hline Total & & 114 & & 95 & & 209 & \\
\hline
\end{tabular}

$\mathrm{n}=$ number of examined birds $\quad$ No.=positive number

$\%$ was calculated according to number (n) of examined bird.

Table (2): Serotyping of E.coli

\begin{tabular}{|c|c|c|}
\hline & \multicolumn{2}{|c|}{ Total no. of isolates $n=45$} \\
\hline Serogroups & No. & $\%$ \\
\hline $\mathrm{O} 78$ & 33 & 88.89 \\
\hline $\mathrm{O} 26$ & 3 & 8.89 \\
\hline $\mathrm{O} 1$ & 5 & 22.22 \\
\hline $\mathrm{O} 2$ & 4 & 20 \\
\hline Total & 45 & \\
\hline
\end{tabular}

Kafrelsheikh Vet. Med. J. Vol. 7 No. 1 (2009) 


\section{REFERENCES}

- Abdel- Alim, F. A.; Amer, M. S.; Ramadan, O. E.; Mohamed, T. A. and Nagah, O. E. (2000): Efficacy of ofloxacin against induced colibacillosis in broiler chicks. J. Vet. Med. Res., 2(1):113-123.

- Akgul, A. and Ayar, A. (1993): Yerli Bahara Akgul A, Ayar A (1993) Yerli Baharatlam Antioksidan Etkileri Turkish, Journal of Agriculture and Foresty 17: 1061-1068.

- Aquirre,A. A.; Quan, T. J.; Cook, R. S.and Mclean, R. G. (1992): Cloacal flora isolated from wild back-belled whisting ducks (Dendrocygna autunmalis) in Laguna La Nacha, Mexico. Avian Dis.,36(2):459-462.

- Ariana A,Ebadi R, Tahmasebi G (2002): Laboratory evaluation of some plant essences to control Varroa destructor (Acari: Varroidae). Experimental and Applied Acarology. Amsterdam: Vol. 27, Iss. 4; pp. 319.

- Aruji, Y.; Tamura, k.; Sugita, S. and Adachi, Y. (2004): Intestinal microflora in 45 crows in ueno Zoo and the invitro susceptibility of 29 Escherichia coli isolates to 14 antimicrobial agents. J Vet. Med Sci., 66 (10):1283- 1286.

- Badr, Y. A. (2003): Evaluation of both drugs and preventive methods used for protection from Salmonella and E. coli infections in chickens. Ph. D. Thesis, Pharmacology Dept., Fac. Vet. Med., Zag. Univ..

- Bauditz, R.(1990): Enrofloxacin, clinical evaluation in several animals' species. Veterinary Pharmacology, Toxicology and Therapy in Food Producing Animals, 21-260 
- Barnes, H. J. and Gross, W. B. (1997): Colibacillosis In: Calnek, B. W.; Barnes, H. J.; Beard, C. W.; McDouglad, L. R. and Saif, Y. M. (eds), Diseases of Poultry, $10^{\text {th }}$ ed., pp:131, Iowa Stat University Press, Ames, Iowa, U. S. A..

- Botsoglu, N. A; Florou-Paneri, P; Christaki, E; Fletouris, D. J Spais, A. B (2002): Effect of dietary oregano essential oil on performance of chickens and on iron induced lipid oxidation of breast thigh and abdominal fat tissues British Poultry Science, 43: 223-230

- Botsoglu N.A, Fletouris D.J, Florou-Paneri P, Christaki E, Spais A.B (2003): Inhibition of lipid oxidation in long-term frozen stored chicken meat by-tocopheryl acetate supplementation. Food Research International 36: 207-213.

- Brittingham, M. C.; Temple, S. A. and Duncan, R. M. (1988): A survey of prevalence of selected bacteria in wild birds. J. Wild Dis. 24 (2):299-307.

- Burt, S. A. and Reinders, R. D.(2003): Antibacterial activity of selected plant essential oils against Escherichia coli O157:H7 The Society for Applied.

- Campbell, T. W. and Coles (1986): Avian Clinical Pathology In: Coles, E., Vet. Clin. Pathol., 4th Ed., pp: 279-301.

- Caraway, W. T. (1963): Standard Methods of Clinical Chemistry. Edited by Seligsol, D. Academic Press, New York and London, 4.

- Charleston, B.; Gate, J. J.; Aitken, I. A.; Stephan, B. and Froyman, $\boldsymbol{R}$. (1998): Comparison of the efficacies of three fluoroquinolones antimicrobial agents given as continuous or pulsed medication against Echerichia coli infection in chicken. Antimicrob. Agents and Chemother., 42 (1): 83-87. 
- Choi, WS; Park, BS; Ku, SK; Lee, SE (2002): Repellent activities of essential oils and monoterpenes against Culex pipiens pallens. J. Am. Mosq. Control Assoc.18 (4): 348-51.

- Chun, S. S.; Vattem, D. A.; Lin, Y. T. and Shetty, K. (2005): Phenolic antioxidant from clonal organo (Origanum vulgare) with antimicrobial activity against Helicobacter pylori. Process Biochemistry, 40: 809- 819.

- Coles, E. H. (1986): Veterinary Clinical Pathology. $4^{\text {th }}$ ED., W.B., Saunders Company. Philadelphia. London and Toronto.

- Cooke, C.; Carr, I.; Abrams, K. and Mayberry, J. (2000): Arrow root as a treatment for diarrhea in irritable Powel syndrome patients. Arq. Gastenterol. 37, 20-24.

- Cowan M.M (1999): Plant products as antimicrobial agents Clinical Microbiology Reviews, October, 564-582.

- Dalia,A. El-Shazly(2007): The effect of concurrent use of marbofloxacin and jojoba oil in quails. Ph.D thesis (Dept. of pharmacology) Zagazig Vet. Med.

- Domas, B. T.(1975):"Standard Method for Clinical Chemistry", vol.7, Academic Press, New York. Clinical Chemistry, 21:10.Acta, 31-78.

- Dragland S, Senoo H, Wake K, Holte K, Blomhoff R (2003): Several Culinary and Medicinal Herbs Are Important Sources of Dietary Antioxidants1. Nutr., 133: 1286-1290

- Dulger, B. (2005): An investigation on antimicrobial activity of endemic Origanum solymicum and Origanum bilgeri from Tyrkey. Afr. Trad., Complementary and Alternative Medicine, 2 (3): 259-263. 
- Dursun N, Liman N, Ozyazgan I,Gunes I, Saraymen R (2003): Rol of thymus oil in burn wound healing. J. Burn Care Rehabil, 24(6): 395-390.

- Fatma,M.Yousseff;Mona,A. Ahmed and Dalia H. Mansour. (2008): Epidemiological studies on bacteriological aspects of air sacculitis in chickens. Assiut Vet. Med. J., 54(118): 284-300.

- Fernandez, A.; Lara, R.; Puyuelo, J.; Ramos, J. J.; Loste, A.; Marca, M. T. and Verde, M. T. (1998): Efficacy of phosphomycin in the control of Escherichia coli infection of broiler chickens. Research in Veterinary Science, 65, 201-214.

- Fraser, M.; A. Bergeron; A. Mays and Aiello, E. Susan (1991): The Merck Veterinary Manual $7^{\text {th }}$ Ed. Rahway, N.J. U.S.A.

- Harpaz,S.; Glatman, L.; Drabkin, V. and Gelman, A. (2003): Effects of herbal essential oils used to extend the shelf life of freshwaterreared Asian sea bass fish.(Lates calcarifer) J Food Prot. Mar:66 (3):410-7

- Harr, K. E. (2002): A review: Clinical chemistry of companion avian spesies. Vet. Clin. Pathol., 31 (1).

- Hassan, W. M. and Gaber, M. Z. (2004): Some bacteriological and biochemical studies on ofloxacin in healthy and E. coli infected broiler chickens. J. Vet. Med. Assoc., 64 (1): 41-57.

- Hedawy, K. A. A. and Wassel, F. A. A. (2005): Studies on some bacterial agents causing mortalities in quail farms in Kena Province. Ass. Vet. Med. J., 51 (105): 274-280.

- Henry, R. J. (1964): "Clinical Chemistry, Principles and Techniques". New York: Harper and Row Publishers, p. 181. 
- Hubalek, Z. ; Pacovaz; Halouzka, J. ; Sedlacek, I. ; Dlouhy, M. and Honza, M. (1998): Selective isolation of Pseudomonas stutzeri from vertebrate faeces on Rambach agar. Zentralbl. Bakteriol., 288(3): 343349.

- Jain, N. C. (2000): Schalm's veterinary hematology. 8th Ed. Lea and Febiger, Philadelphia,U.S.A..

- Ibrahim, Dalia, M.(2005): Effect of marbofloxacin and probiotic (nutrilac) in chickens. M.V.Sc. Thesis, Vet. Pharmacology Dept., Fac. Vet. Med., Zag. Univ..

- Kirkpatrick, C. E. and Trexler Myren, V P. (1986): A survey of free living falconiform birds for salmonella. J. Am. Vet. Med. Assoc. No1, 189 (9): 997-998.

- Kobayashi, H.; Kanazaki, M.; Shimizu, Y.; Nakajima, H.; Khatun, M . M.; Hata, E. and Kubo, M. (2007): Salmonella isolates from cloacal swabs and footpads of wild birds in the immediate environment of Tokyo Bay . J. Vet. Med. Sci., 69(3): 309-311.

- Koli, A. S. and Iroegbu, C. U. (2004): Evaluation of extracts of Anthocleista djalonensis, Nauclea latifolia and Uvaria afzali for activity against bacterial isolates from cases of non-gonococcal urethritis. J. Ethnopharmacol., 92, 135-144.

- Levre, E.; Valentini, p.; Brunetti, M.; Sacchelli, F. (1989): Stationary and migratory avifauna as reservoirs of Salmonella, Yersinia and Campylobacter. Ann. Ig., 1 (3-4): 729-740.

- Martin, K. W. and Ernst, E. (2003): Herbal medicines for treatment of bacterial infections: A review of controlled clinical trials. J. Antimicrobial Chemotherapy, 51, 241-246. 
- Matsuura, H.; Chiji, H.; Asakawa, C.; Amano, M.; Yoshihara, T. and Mizutani, J.(2003): DPPH radical scavengers from dried leaves of oregano (Origanum vulgare). Biosci. Biotechnol. Biochem. 67: 2311-2316.

- Mauch, C. and Bilkei, G. (2004): Strategic application of oregano feed supplements reduced sow mortality and improves reproductive performance - a case study. J. Vet. Pharmacol. Therap., 27: 61-63.

- Mellata, M.; dho-Moulin, M.; Dozois, C. M.; Curtiss, R.; Brown, P. K.; Arne, P.; Bree, A.; Desautles, C. and Fairbrither, J. M.(2003): Role of virulence factors in resistance of avian pathogenic Escherichia coli to serum and in pathogenicity. Infect. Immun., 71 (1): 563-540.

- Middleton, J. h. and Ambrose, A. (2005): Enumeration and antibiotic resistance patterns of fecal indicator organisms isolated from migratory Canada gees (Branta Canadensis). J. Wild Dis 41(2): 334341.

- Mohammad, Hebato-Allah, A. and Foud, I. A. (2004): Studies on effect of E. coli on ocular and subcutaneous tissues in broiler chickens. Ass. Vet. Med. J., 50 (102): 263-275.

- National Committee for Clinical Laboratory Standards (NCCLS) (2002): Performance standards for antimicrobial discs and dilution susceptibility for bacteria isolated from animals. Approved StandardsSecond Edition, vol. 22, pp. 1-52.

- Palmgren, H.; Sellin, M.; Bergstrom, S. and Olsen, B. (1997): Enteropathogenic bacteria in migrating birds arriving in Sweden .Scand. J. Infection Dis., 29(6):565-568.

- Petermann, S.; Glunder, G.; Heffels-Redmann, U. and Hinzk, H. (1989): The (diseased) or (dead) guillemots (Uria aagle), three- toed gulls (Rissa tridactyla), Silver gull (Larus argentatus) and laughing gulls (Larus ridibundus) found in the area of German Bay ,1982-1985 .Dtsch Tierarl Wochenschr., 96(5): 271-277. 
- Pizzale, L.; Bortolomeazzi, R.; Vichi, S.; Uberegger, E. and Conte, L. (2002): Antioxidant activity of sage (Salvia officinalis and $S$. fruticosa) and Oregano (Origanum onites and Origanum indercedens) extracts related to their phenolic compound content. J. Sci. Food Agric., 82: 1645-1651.

- Quinn, P.J.; Carter, M.E.; Markey, B.K. and Carter, J.R. (1994): Clinical Veterinary Microbiology. Wolf Publishing Travistock Londomn, pp.:220-242.

- Quinn, P. J.; Markery, B. K.; Carter, M. E.; Donnelly, W. J. and Leonard, F. C. (2002): Veterinary Microbiology and Microbial Diseases. Block well Science Ltd. 1st Published

- Reitman, S. and Franel, S. (1957): A colorimetric method for determination of serum glutamic oxaloacetate and glutamim pyruvic transaminases. J. Clin. Path., 28: 56.

- Shawkey, M. D.; Mills, K. L.; Dale, C. and Hill, G. E. (2005): Microbial diversity of wild bird feathers revealed through culturebased and culture- independent techniques. Microb. Ecol. Jul.; 50(1):407. Epub. Aug, 18.

- Sheer, M. (1987): Concentration of active ingredient in the serum and in tissues after oral and parental administration of Baytril, Vet. Med. Rev., 2, 104-118.

- Snedecor, G. W. and Cochran, W. G. (1982): Statistical Method $7^{\mathrm{ed}}$. Iowa State, U. S. A..

- Steal R. G. and Torrie, J. H. (1980): Principle and Procedures of Static. A Biochemical Approach (2 ${ }^{\text {nd }}$ Ed.) McGavous Hill Booh Company, New York, U.S.A..

- Szeness, L.; Sey, L. and Szeness A. (1979): Bacteriological studies of the intestinal content of aquatic birds, fishes, and frogs with special refrence to the presence of non cholera vibrios (NCV) (author,s Transl).Zentralbl Bakteriol (origA). Oct ;245(1-2). 89-95. 
- Thrall, M. A.; Baker, D. C.; Campbell, T. W.; DeNicola, D.; fettman, M. J.; Lassen, E. D. and Rebar, A. (2004): Clinical Chemistry of Birds. In: Veterinary Haematology and Clinical Chemistry, Lippincot Williams and Wilkins, U. S. A., P: 479-492.

- Tsubokura, M.; Matsumoto, A; Otsuki, K.; Animas, S. B. and Sanekata, T. (1995): Drug resistance and conjugative R plasmids in Escherichia coli strains isolated from migratory waterfowl. J. Wild Dis., 31(3): 352-370.

- Uslu, C.; Karasen, MR.; Sahin, F.; Taysi, S.; Akcay, F. (2003): Effects of aqueous extracts of

- Satureja hortensis L. On rhinosinusitis treatment in rabbit. Journal.of Ethno pharmacology 88, 225-228

- Walter, BM. and Bilkei, G. (2004): Immunostimulatory effect of dietary oregano etheric oils on lymphocytes from growth-retarded, low-weight growing-finishing pigs and productivity. Tijdschr Diergeneeskd. 15:129(6):178-181.

- Wang, R. D. and Bourne, S. (1998): Biotechnology in the feed industry Proceedings of Alltech's 14 th Annual Symposium Alltech Technical PublicationsNottingham University Press. Nicholasville. K.Y. pp. 273-292.

- Youdim, KA. and Deans, SG. (2000): Effect of thyme oil and thymol dietary Supplementation on the antioxidant status and fatty acid composition of the ageing rat brain Br J Nutr. Jan:83(1):87-93

- Young, D.; Pestaner, L. and Giberman, V. (1975): Clinical Chemistry, $21: 10$

- Zherng, W. and Wang, SY. (2001): Antioxidant activity and phenolic compound in selected herbs, j. Agric. Chem., 94: 5165-5170. 


\section{تأثير استخلام البردقوش كمضاد للبكتيريا والتفيرات المصاحبة على مكونات الدم في الدواجن.}

\section{كوثر حسبن صباح'- فاطمة محد بيوسف 1- أثرف أحمد الغتيسى2}

1معه بحوث صحة الحيوان و 2كلة الطب البيطري - قنا - جامعة جنوب الوادي

إن ضرورة اكتشاف مضدات ميكروبية جديدة فى جميع مجالات مقاومة الميكروبات قد

نشطت البحوث العلمية المتعلقة بدر اسة بعض المركبات النباتية التي لها خصائص قتل الميكروبات. أجريت هذه الدراسة لبحث التأثير المثبط لمستخلص نبات البردقوش المائي على الميكروبات خارج الجسم الحي (معمليا") و داخله. وقد أجريت الدراسة المعملية على بعض الميكروبات الممرضة مثل الميكروب العصوي القولوني؛ ميكروب السيدومونس؛ ميكروب السلمونيلا؛ ميكروب البر ونتس فلجارز ؛ البكتيريا المعوية و ميكروب المكور العنقودي الذهبي المعزولة من عدد 60 مسحة مأخوذة من المستقيم من طيور مريضة بلاضافة إلى عينات كبد؛ أمعاء؛ طحال و كلى مأخوذة من عدد 25 من الطيور حديثة النفوق وذللك من احد مز ارع فر اخ التسمين الصغيرة الخاصة الكائنة بالاسملعيلية.و قد أظهرت النتائج المتحصل عليها أن الخلاصة المائية لنبات البردقوش كانت لها فاعلية ضد جميع الميكروبات الممرضة موضوع الدر اسة. أما كفاءة هذا المستخلص داخل الجسم الحي فقد تم در استها باستخدام عدد 120 كتكوت تسمين عمر يوم واحد سلالة لوهمان سليمة ظاهريا" و غير مجنسة. قسمت هذه الكتاكيت في عمر 15 يوم عشو ائيا إلى 6 محموعلت منساوية قو ام كل مجموعة 20 كتكوت. المجموعة الأولى غير معدية و غير معالجة (ضابطة)؛ المجموعة الثانية غير معدية و معالجة بالمستخلص المائي لنبات البردقوش؛ المجموعة الثالثة معدية عدوى محدثة تجريبيا" بالميكروب القولوني العصوي و غير معالجة؛ المجموعة الرابعة معدية ومعالجة بالخلاصة المائية لنبات البردقوش، المجموعة الخامسة معدية و معالجة بدواء السيبروفلوكساسين أما المجموعة السادسة فهي معدية و معالجة بكل من الخلاصة المائية لنبات البردقوش و السيبروفلوكساسين معا". 
بدأت العلاجات جميعها بعد مرور 48 ساعة من العدوى ( أي بعد ظهور الأعر اض ) و استمرت لمدة 5 أيام متتالية في مياه الثرب. فى اليوم الثاني، التاسع و السادس عشر بعد انتهاء مدة العلاج تم ذبح عدد 5 طيور من كل مجموعة وتم أخذ عينات دم غير متجلط (للفحص الادوي)، دم متجلط للحصول على المصل (للقياسات البيوكيميائية) و أنسجة (للعزل البكتيري). و قد أظهرت النتائج قدرة المستخلص المائي لنبات البردقوش على تقليل معدل الوفيات من 25\% بالمجموعة الثالثة إلى 15\% بالمجموعة المعدية الر ابعة و صفر \% بالمجموعات السادسة و الخامسة. هذا وقد أظهرت كل المجموعات المعدية و المعالجة انخفاضا" شديدا" في حدة الأعر اض و كذلك الآثار المرضية أثناء الصفة التشريحية و بالأخص تلك بالهموعة السادسة و الخامسة. هذا و قد أظهرت الفحوصات الدموية حدوث زيادة معنوية واضحة في عدد الخلايا الدموية الليمفية و ذلك في الدجموعات الثانية، الرابعة و السادسة. أما الفحوصات البيوكيميائية فقد أظهرت نتائجها أن العلاج باستخدام الخلاصة المائية لنبات البردقوش وعقار السيبروفلوكساسين كلا" على حده أو كلاهما معا" له القدرة على إحداث تحسن ملحوظ في وظائف كلا" من الكبد والكلى مقارنة بالمجموعة الثالثة وقد خلصت هذه الدراسة إلى تأكيد قدرة الخلاصة المائية لنبات البردقوش على تتبيط جميع الميكروبات المعزولة معمليا" وكنلك قدرته على صد عدوى الميكروب القولوني العصوي المحدثة تجريبيا في بداري التسمين. هذا وقد دعمت هذه الدراسة إمكانية استخدام الخلاصة المائية لنبات البردقوش مع المضادات البكتيرية المعروفة وذلك لزيادة المناعة و الفاعلية مع الحد من حدوث المقاومة البكتيرية لتلك المضادات. هذا وماز الت هناك الحاجة إلى إجر اء العديد من الدراسات المستقبلية لتأكيد كفاءة هذا الخلاصة كمضاد للميكروبات وكذلك تقييم كفاءته في صد عدوى الميكروبات الممرضة واستبيان كيفية العمل. كما أن هناك حاجة إلى عملية فصل مكونات هذا المستخلص لتحديد وعزل المكون المسئول عن هذا. 